\title{
SURGICAL MANAGEMENT OF INTRAMEDULLARY SPINAL EPENDYMOMAS
}

\author{
Andrei Fernandes Joaquim?', Marcos Juliano dos Santos ${ }^{1}$, Hélder Tedeschi²
}

\begin{abstract}
Background: Spinal intramedullary ependymoma is a rare disease with a wide range of clinical presentation, generally requiring surgical treatment. Objective: Report our experience and present our surgical technique to achieve total resection and cure. Method: We present 12 consecutive cases of intramedullary ependymomas operated between 2000 and 2008 by the senior author (HT). The functional scale proposed by McCormick was used to evaluate the patients' neurological status. Results: Age at presentation varied from 18 to 55 (average 36) years. All tumors had a benign histology. Four (33\%) patients were male and eight (67\%) were female. According to the site of presentation, six (50\%) were localized at the cervical region (including two at the cervicomedullary junction, two at the cervico-thoracic junction and two exclusively at the cervical level), four at the thoracic level and two at the conus/ cauda equina. Dyshestesia was a common finding at the neurological exam in eight patients (67\%). Total resection was achieved in all cases. Six patients showed neurological improvement postoperatively, whereas the other six remained stable. Conclusion: Adequate knowledge of anatomy and the correct use of microsurgical techniques allowed total resection of these tumors with minimal morbidity and maximum functional recovery.
\end{abstract}

KEY WORDS: intramedullary, ependymomas, surgery.

\begin{abstract}
Abordagem cirúrgica dos ependimomas intramedulares
Resumo - Introdução: Os ependimomas intramedulares são lesões raramente encontradas na prática neurocirúrgica, tendo apresentação clínica variada, geralmente requerendo tratamento cirúrgico. Objetivo: Relatar nossa experiência e discutir a técnica microcirúrgica para a ressecção total e conseqüente cura destas lesões. Método: Apresentamos uma série de 12 casos de ependimomas intramedulares operados sucessivamente entre 2000 e 2008 pelo autor sênior (HT). A evolução neurológica foi avaliada através da classificação funcional de McCormick. Resultados: A idade dos pacientes variou de 18 a 55 anos (média de 36 anos). Todos eram histologicamente benignos. Quatro (33\%) eram do sexo masculino e oito do feminino (67\%). A localização das lesões esteve distribuida da seguinte forma: seis casos (50\%) na região cervical (sendo dois na transição cérvico-bulbar, dois na região cérvico-torácica e dois na região cervical isoladamente), quatro na região torácica e dois no nível do conus-cauda-eqüina. Disestesias estavam presentes em oito pacientes no pré-operatório (67\% dos casos). A ressecção total foi atingida em todos os casos. Em seis casos (50\%), houve melhora dos sintomas neurológicos, enquanto que nos outros seis houve manutenção do quadro clínico. Conclusão: $O$ conhecimento anatômico e de técnicas microcirúrgicas adequadas permite a ressecção total destas lesões propiciando a cura da doença com mínima morbidade e máxima recuperação funcional.
\end{abstract}

PALAVRAS-CHAVE: intramedulares, ependimomas, cirurgia.

Ependymomas are derived from ependymal cells that are located in the central canal of the spinal cord and constitute one of the commonest primary intramedullary tumors'. Most of them are hystologically benign, with a low infiltrative potential that in many cases allows com- plete surgical removal due to the presence of a cleavage plane. Almost $50 \%$ of intramedullary tumors in adults are ependymomas, consisting in slow-growing lesions that may involve different cord levels with a wide range of clinical symptoms ${ }^{2-6}$. Magnetic resonance is the gold stan-

Division of Neurosurgery, Department of Neurology, Campinas State University (UNICAMP), Campinas SP, Brazil: 'Resident of Neurosurgery; ${ }^{2}$ Professor of Neurosurgery.

Received 21 October 2008, received in final form 5 December 2008. Accepted 27 February 2009.

Dr. Hélder Tedeschi - Rua Mato Grosso 128 / Conj 71 -01239-040 São Paulo SP - Brasil.E-mail: hekamarated@mail.com 
dard exam for the diagnosis of these lesions, generally showing an iso or hypointense intramedullary mass on $\mathrm{T} 1$ sequence, sometimes associated with rostral and/ or caudal cystic lesions, with well defined borders and homogeneous contrast enhancement. Heterogeneity and hyperintense signal on T1-weighted images may be consistent with a hemorrhagic component of the mass that may sometimes be clinically represented by strong headaches, similar to those of cranial subarachnoidal hemorrhage. Clinical symptoms depend on the size and topography of the lesion, but most frequently are insidious and non-specific, what can lead to a late diagnosis. Total surgical resection is the treatment of choice, as it can result in cure and functional improvement. When total surgical resection is achieved, postoperative radiotherapy can be avoided, decreasing complications and morbidity ${ }^{7,8}$.

We retrospectively reviewed 12 cases of intramedullary ependymomas operated by the senior author $(\mathrm{HT})$, reporting clinical aspects and emphasizing the microsurgical techniques used.

\section{METHOD}

We present 12 cases of intramedullary ependymomas successively operated by the senior author (HT) between 2000 and 2008 at the Hospital of the University of the State of Campinas (UNICAMP). The neurological status before and after surgery was evaluated according to the McCormick scale ${ }^{7}$. Radiological findings and the lesions' topography was also reported ${ }^{7}$. All patients were operated without electrophysiological monitorization, unavailable in our service.

Patients were operated on in the prone position. Prophylatic antibiotics (first generation cephalosporin) and $10 \mathrm{mg}$ dexamethasone IV bolus was used in all cases.

All tumors were surgically removed under microscope magnification. A posterior midline incision was performed after radiological confirmation of the desired levels, followed by subperiostal dissection of the muscles until complete laminar exposure. A non-expandable laminoplasty using the open-door technique after new radiological confirmation of the correct levels was performed, exposing one level above and one below the level of the lesion. For the upper thoracic and cervical lesions
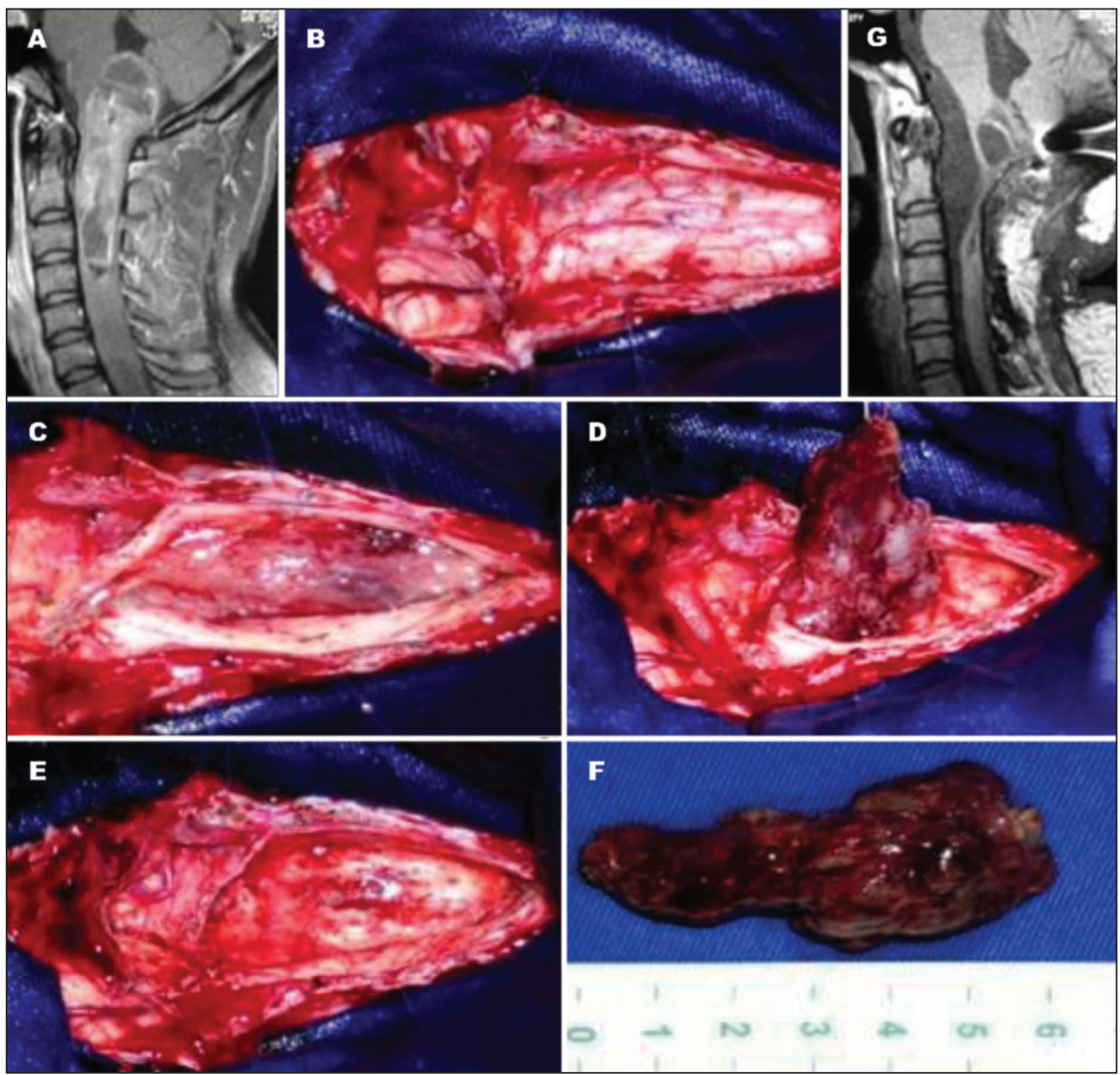

Fig 1. Surgical approach to an ependymoma of the cervicomedullary junction. Patient with an ependymoma of the cervicomedullary transition: [A] Preoperative MRI; [B] After opening and anchoring the dura, before the myelotomy; [C] Tumor exposure after myelotomy; [D] Tumor resection; [E] Medulla and cervical spine after complete remotion; [F] A $6 \mathrm{~cm}$ tumor is exposed; [G] postoperative MRI. 


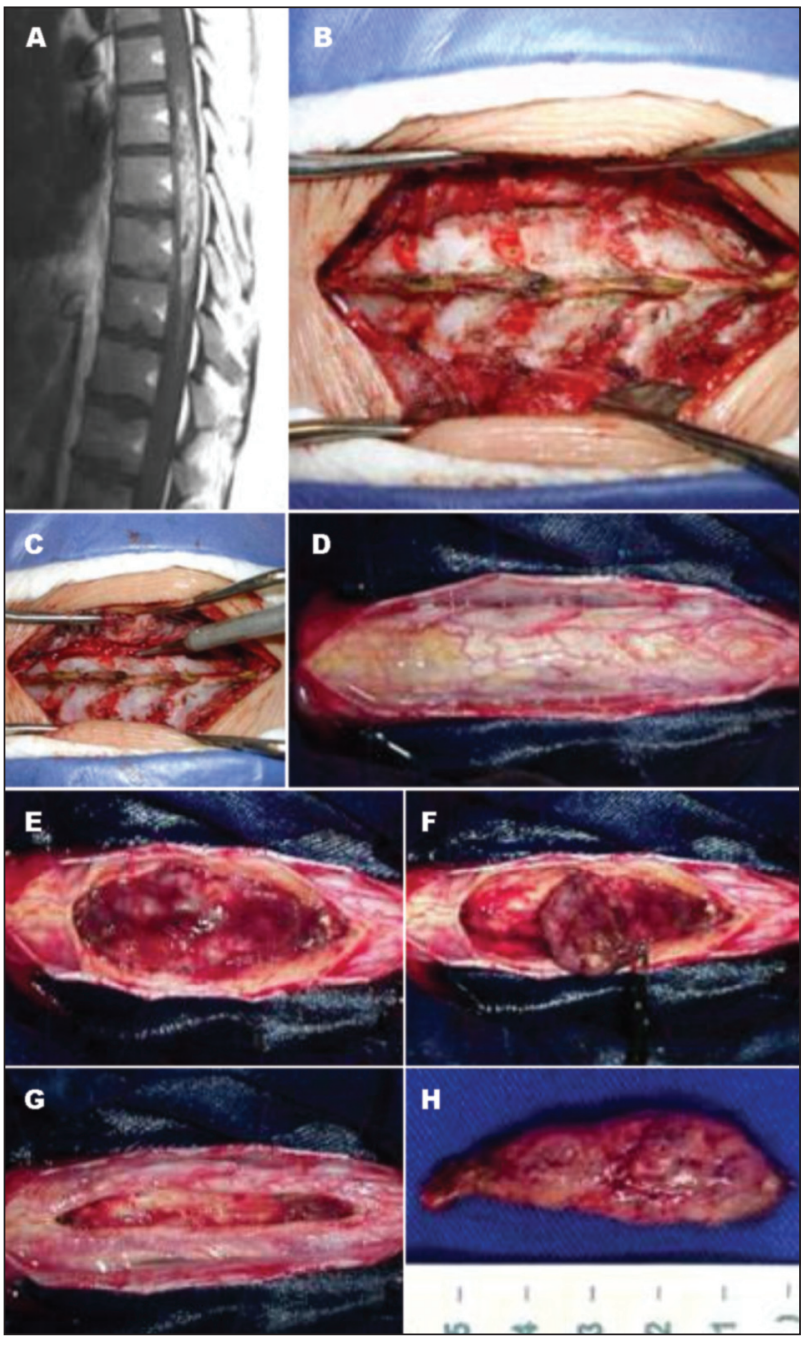

Fig 2. Thoracic ependymoma. [A] Preoperative MRI; [B and C] Lamina exposure and laminotomy; [D] Spinal cord after myelotomy; [E and F] Tumor exposure after myelotomy and resection; [G] Spinal cord after total tumor remotion' $[\mathrm{H}]$ Tumor removed. the head was fixed in a Sugita device. In the two cervicomedullary tumors, we performed a median suboccipital craniotomy, opening the foramen magnum and removing the posterior arch of $\mathrm{C} 1$ and the lamina of $\mathrm{C} 2$. The dura-mater was opened longitudinally and anchored with sutures laterally. The arachnoid was then opened using microscope magnification and a posterior midline myelotomy was performed with sharp instruments after superficial low voltage bipolar coagulation of the spinal cord using $0.5 \mathrm{~mm}$ forceps. Identification of the interface between normal neural tissue and tumoral tissue is an essential step for total surgical resection, using adequate microdissectors. The presence of cysts can be helpful in finding an adequate surgical plane. Lateral anchoring of the pia mater with 7.0 sutures can be extremely useful for gently retracting the spinal cord, thus helping tumor exposure and dissection. Avoiding bipolar cauterization is important in order to minimize damage to the normal tissue. Branches of the anterior spinal artery found at the anterior surface of the tumor should always be carefully dissected before being judiciously cauterized. Although advocated by some authors ${ }^{8}$, we try to avoid tumor debulking, as it usually results in loss of the surgical interface between tumor and normal neural tissue (Figs 1, 2 and 3).

\section{RESULTS}

Age varied from 18 to 55 years (36 average). Seven patients had a cellular ependymoma whereas five had a mixopapillary histology. Four (33\%) patients were males and eight $(67 \%)$ were females (Table 1$)$.

The topography of the lesions is also showed in Table 2, with $50 \%$ of the tumors being located in the cervical spine (including cervicomedullary and cervico-thoracic junction).

Clinical findings: 8 patients (67\%) had painful dysesthesias, the most common clinical finding, whereas 6 had long

Table 1. Distribution of twelve patients with spinal cord ependymomas: topography, age, neurological status before and after surgery and surgical complications.

\begin{tabular}{|c|c|c|c|c|c|}
\hline Patient & Topography & Age & $\begin{array}{c}\text { McCormick Scale } \\
\text { before surgery }\end{array}$ & $\begin{array}{c}\text { McCormick Scale } \\
\text { after surgery }\end{array}$ & Complication \\
\hline 1 & $C$ & 31 & II & I & \\
\hline 2 & $\mathrm{CT}$ & 31 & II & II & Kyphosis \\
\hline 3 & $\mathrm{~T}$ & 29 & I & I & \\
\hline 4 & $\mathrm{C}$ & 44 & II & 1 & \\
\hline 5 & $\mathrm{CT}$ & 37 & II & II & Kyphosis \\
\hline 6 & $\mathrm{CC}$ & 32 & II & I & \\
\hline 7 & $\mathrm{~T}$ & 51 & I & I & \\
\hline 8 & $\mathrm{~T}$ & 55 & II & II & \\
\hline 9 & $\mathrm{CB}$ & 34 & III & II & \\
\hline 10 & $C B$ & 33 & II & I & \\
\hline 11 & $\mathrm{CC}$ & 18 & II & I & \\
\hline 12 & $\mathrm{~T}$ & 33 & II & II & \\
\hline
\end{tabular}

CB: cervicomedullary; C; cervical; CT: cervico-thoracic; $\mathrm{T}$ : thoracic; $\mathrm{CC}$ : conus and cauda equina 

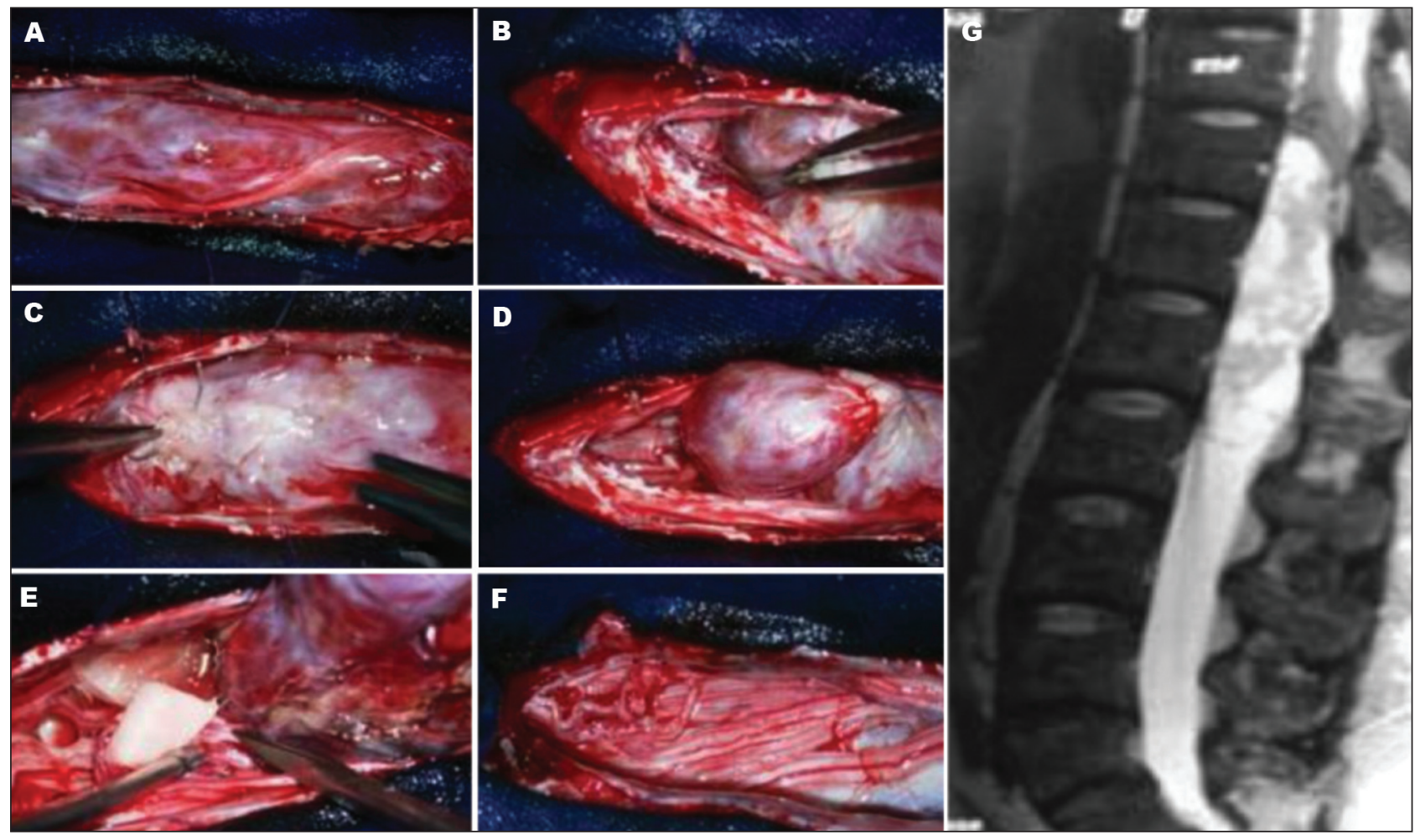

Fig 3. Conus and cauda equina ependymoma. [A] Initial exposure; [B] Superior pole dissection; [C and D] Superior retraction with suture; [E] Roots dissection; [F] Final aspect after tumor resection; [G] preoperative MRI.

tract dysfunction, 2 had cauda equina syndrome, 1 had chorea syndrome and 1 patient was asymptomatic.

At the immediate postoperative evaluation, the patients generally remained neurologicaly stable: there was no great improvement nor deterioration of the clinical status in the first days. At the late follow-up (5 months -6 years) we had a significant neurological improvement in 6 patients. Important is to note that amongst those patients that did not show neurological improvement in our series (6 patients) 2 were neurologically intact in the preop evaluation (McCormick I) and remained so in the postop. None of our patients had severe functional disabilities (McCormick IV) before surgery.

Cervical kyphosis was observed in two cases (both on cervico-thoracic junction with more than 3 level laminoplasty), that required posterior instrumentation and fusion, but with no additional neurological deterioration.

There was not a single case of radiological residual tumor or late relapse in the control MRI in our serie (followup of 5 months to 6 years, median of 37 months).

\section{DISCUSSION}

Intramedullary tumors have a wide range of presentations. It is among the differential diagnosis of many spine pathologies, like benign mechanical pain of inflammatory diseases or spinal metastasis ${ }^{9,10}$. Axial pain is reported in up to $60-70 \%$ of the cases ${ }^{8}$. Similar to our findings some authors reported that $10 \%$ of their patients had radicular pain or dysesthesias and about $50 \%$ presented with long tracts deficits. Tactile and pain sensation are usually afected first, because of the central topography of these tumors ${ }^{8}$. Except in conus or cauda equina tumors, sphincter dysfunction is not common ${ }^{7}$. Acute neurological deterioration is rare, but can present after intratumoral hemorrhage, especially with the more vascularized papillary histology ${ }^{6}$.

MRI is the radiological exam of choice, either for surgical planning or to rule out differential diagnosis 9 . Focal and symmetric spinal cord expansion is generally noted, differently from astrocytomas, the second most common lesions, which present more diffuse and heterogeneous characteristics. Ependymomas have a homogeneous contrast enhancement, with well defined poles, and many present with cranial or caudal cysts ${ }^{8}$.

Once they are not infiltrative, their morbidity is caused by mass effect and compression of the nervous tissue. Neurological status before surgery is one of the most important factors affecting clinical prognosis of these patients ${ }^{3,7,8}$. In our series, using microsurgical techniques of dissection, just 2 out of the twelve patients had a mild deterioration in the immediate postoperative period. We could notice that with meticulous surgical tech- 
Table 2. Topography of intramedullary ependymomas in different series.

\begin{tabular}{lcccccc}
\hline Authors & $\mathrm{N}$ & Cervicomedullary & Cervical & Cervico-thoracic & Thoracic & Conus and equine cauda \\
\hline Hoshimaru et al., 1999 & 36 & $2(5 \%)$ & $22(61 \%)$ & $3(8 \%)$ & $7(19 \%)$ & $2(5 \%)$ \\
McCormick et al., 1990 & 23 & 0 & $14(61 \%)$ & $3(13 \%)$ & $2(86 \%)$ & $4(17 \%)$ \\
Epstein et al., 1993 & 38 & $12(32 \%)$ & - & $12(32 \%)$ & $10(26 \%)$ & $4(11 \%)$ \\
Hanbali et al., 2002 & 26 & $2(8 \%)$ & $11(42 \%)$ & $5(19 \%)$ & $4(15 \%)$ & $4(15 \%)$ \\
Sgouros et al., 1996 & 38 & & $11(29 \%)$ & & $10(26 \%)$ & $17(45 \%)$ \\
Joaquim et al., 2008 & 12 & $2(17 \%)$ & $2(17 \%)$ & $2(17 \%)$ & $4(33 \%)$ & $2(17 \%)$ \\
\hline
\end{tabular}

Table 3. Comparative resection and relapse rates of intramedullary ependymomas in different series.

\begin{tabular}{lccc}
\hline Authors & $\mathrm{N}$ & Total resection & Partial resection and/ or relapse \\
\hline McCormick et al., 1990 & 23 & $22(96 \%)$ & $1(4 \%)$ \\
Yoshii et al., 1999 & 8 & $6(75 \%)$ & $2(25 \%)$ \\
Asazuma et al., 1999 & 26 & $15(58 \%)$ & $11(42 \%)$ \\
Epstein et al., 1993 & 38 & $37(97 \%)$ & $1(3 \%)$ \\
Hanbali et al., 2002 & 26 & $23(88 \%)$ & $3(12 \%)$ \\
Joaquim et al., 2008 & 12 & $12(100 \%)$ & 0
\end{tabular}

Table 4. Comparative neurological evaluation at late follow-up in different series of intramedullary ependymomas in the literature.

\begin{tabular}{lcccc}
\hline & \multicolumn{3}{c}{ Late neurological status } \\
\cline { 2 - 5 } Authors & $\mathrm{N}$ & Improvement & Deterioration & Stable \\
\hline Hoshimaru et al., 1999 & 36 & $14(39 \%)$ & $5(14 \%)$ & $17(47 \%)$ \\
McCormick et al., 1990 & 23 & $8(35 \%)$ & $3(13 \%)$ & $12(52 \%)$ \\
Hanbali et al., 2002 & 26 & $7(27 \%)$ & $15(58 \%)$ & $4(15 \%)$ \\
Epstein et al., 1993 & 38 & $2(5 \%)$ & $7(18 \%)$ & $29(76 \%)$ \\
Joaquim et al., 2008 & 12 & $6(50 \%)$ & - & $6(50 \%)$ \\
\hline
\end{tabular}

niques, no significant neurological alteration is noted in the early postoperative period.

Although there is no pathognomonic symptom of intramedullary tumors, Epstein et al. ${ }^{8}$, reported that $100 \%$ of their patients $(n=38)$ had dysesthesias just after surgery. In our series dysesthesias were the most common finding before surgery (eight cases out of twelve, corresponding to $67 \%$ of our patients). Some authors also reported some compromise of proprioceptive sensation after surgery due to the posterior myelotomy, with full recovery in some weeks.

In 2 cases we had a progressive spinal deformity (kyphosis) on radiological follow-up, requiring posterior instrumentation and fusion. In patients submitted to 3 or more levels of cervical laminectomy, with motor symptoms, bone fragilities and in children, concomitant instrumentation and fusion must be considered".
Although ependymomas can be found at any topography in the spinal cord, a cervical predominance can be noted, possibly due to a small number of cases in each series (Table 2).

Age of presentation of ependymomas in the different series reported in the literature varied from 12 to 70 years, with average from 36-43 years-old ${ }^{2,3,7,8}$.

In Table 3, we compared the percentage of total resection and tumor relapse. Total resection rates vary from 58 to $100 \%$ of the cases in all series.

The difference of late neurological outcome among different series (Table 4) can be attributed to many factors, like different tumor topography, surgical techniques, and clinical evaluation. Hoshimaru et al. ${ }^{2}$, suggested that thoracic ependymomas are more susceptible to intra-operative neural tissue injury due to the small diameter of the canal. However, in accordance with other authors, we 
strongly believe that the most important factor influencing the prognosis of these patients is the preoperative neurological status ${ }^{2-4}$.

In conclusion, it is our belief that anatomical knowledge and meticulous microsurgical techniques can improve the outcome of patients with intramedullary ependymomas.

\section{REFERENCES}

1. Torres LFB, Reis Filho JS, Netto MRM. Ependimomas: achados clínicos, epidemiológicos e anatomotatológicos de 22 casos. Arq Neuropsiquiatr 1999;57:261-266.

2. Hoshimaru M, Koyama T, Hashimoto N, Kikuchi H. Results of microsurgical treatment for intramedullary spinal cord ependymomas: analysis of 36 cases. Neurosurgery 1999;44:264-269.

3. Hanbali F, Fourney DR, Marmor E, et al. Spinal cord ependymoma: radical surgical and outcome. Neurosurgery 2002;51:1162-1172.

4. Cooper PR. Outcome after operative treatment of intramedullary spinal cord tumors in adults: intermediate and long-term results in 51 patients. Neurosurgery 1989;25:855-859.

5. Brotchi J, Dewitte O, Levivier M, et al. A survey of 65 tumors within the spinal cord: surgical results and the importance of preoperative magnetic resonance imaging. Neurosurgery 1991;29:651-657.
6. Fehlings MG, Rao SC. Spinal cord and spinal column tumors, em neuro-oncology - the essentials. Bernstein M, Berger MS (Eds). Thieme: New York, 2000:445-464.

7. McCormick PC, Torres R, Post KD, Stein BM. Intramedullary ependymoma of the spinal cord. J Neurosurg 1990;72: 523-532.

8. Epstein FJ, Farmer J-P, Freed D. Adult intramedullary spinal cord ependymomas: the result of surgery in 38 patients. J Neurosurg 1993;79:204-209.

9. Joaquim AF. Abordagem inicial do paciente com mielopatia aguda não compressiva. Rev Bras Med 2007;64:164-169.

10. Joaquim AF, Maturana FAP, Anderle DV, Zambelli HJL, Maldaun MVC. Metástases na coluna vertebral. Rev Neurocienc 2007;15:240-245.

11. Sgouros S, Malluci CL, Jackowski A. Spinal ependymomas-the value of postoperative radiotherapy for residual disease control. Br J Neurosurg 1996;10:559-566.

12. Yoshii S, Shimizu K, Ido K, Nakamura T. Ependymoma of the spinal cord and the cauda equina region. J Spinal Disord 1999;12:157-161.

13. Asazuma T, Toyama Y, Suzuki N, Fujimura Y, Hirabayshi K. Ependymomas of the spinal cord and cauda equina: an analysis of 26 cases and a review of the literature. Spinal Cord 1999; 37:753-759. 